\title{
Supervīzijas darba metodes izglītības vidē
}

\section{Liga Vaite}

Supervīzijā izmantojamo praktiskā darba metožu un tehniku klāsts ir plašs. Metodes izmantošana kā tāda supervīzijā noteikti nav mērķis, drīzāk gan palīgs vai rīks mērḳa sasniegšanai, un, veiksmīgi izvēlēta, tā palīdz mērkstiecīgāk virzīt supervīzijas procesu. Izvēloties metodi, jāņem vērā supervīzijas mērķis, jāsaprot, kādā supervīzijas procesa posmā atrodas supervizējamais vai grupa, kādi ir aktuālie supervīzijas fokusa punkti, jāizprot mērķauditorija, kurā metode tiks lietota.

Pedagoga darbā, plānojot un vadot mācību procesu izglītības iestādē, ir nepieciešama cieša savstarpēja sadarbība. Domājot par supervīzijas metožu izvēli, svarīgi, lai piedāvātās metodes ḷautu skolotājam pašam izvēlēties savu iesaistes un atklātības līmeni, akcentētu uzmanību uz grupas vai komandas locekliem, veicinātu sadarbību, rosinātu risināt aktuālos profesionālos uzdevumus.

Piedāvātās metodes var būt atbalsts ne tikai supervizoriem, tās iespējams adaptēt un izmantot arī skolotājiem savā ikdienas darbā, kā arī darbā ar visdažādāko profesiju klientiem. Metodes paredzētas darbam ar grupu vai komandu dažādos tās attīstības posmos, daḷa no tām pielāgojamas arī individuālajai supervīzijai.

\section{Metodes dalībnieku atraisišsanai un noskaņošanai supervīzijai}

Svarīgs uzdevums, sākot grupas vai komandas supervīziju, ir noskaņoties darbam, ieraudzīt un sadzirdēt citam citu, spēt pārslēgties uz “šeit un tagad”. Šajā posmā reizēm noder vienkāršas metodes.

\section{"Sarunu raundi par aktuālo"}

Mērḳis - saliedēt grupu vai komandu, labāk iepazīt citam citu, aktualizēt savus resursus, veidot supervīzijas pieprasījumu (supervīzijā aktuālos jautājumus).

Nepieciešamie materiāli - supervizora iepriekš sagatavoti 5-6 jautājumi.

Laiks - $50 \mathrm{~min}$. 
L. Vaite. Supervīijas darba metodes izglitīibas vidē

Darba gaita

1. Tiek izveidoti divi apḷi - iekšējais un ārējais, dalībnieki stāv cits citam pretim. Jāievēro distance starp blakusesošajiem dalībniekiem, lai netraucētu stāstīt un klausīties.

2. Iekšējā aplī esošie dalībnieki stāsta vai atbild uz iepriekš uzdoto jautājumu (2 min), tad - ārējā aplī esošie dalībnieki (2 min).

3. Katrs sarunu raunds ilgst 4 min, tad ārējais aplis paliek, stāvot uz vietas, iekšējais mazliet pavirzās pa kreisi, līdz satiek ārējā apḷa nākamo grupas dalībnieku.

4. Raundu skaits nav ierobežots, ieteicams, lai visi dalībnieki cits ar citu būtu satikušies un vienu no tēmām savstarpēji pārrunājuši.

5. Katram raundam ir cits jautājums. Jautājumi veidoti, lai rosinātu grupas vai komandas dalībniekus domāt par sev supervīzijā aktuāliem jautājumiem jeb supervīzijas pieprasījumu.

Jautājumu piemēri:

- Pastāsti, kā tev šodien pagāja darba diena un kā tu jūties šeit!

- Pastāsti par kādu konfliktsituāciju, kuru esi atrisinājis!

- Pastāsti par savu pēdējā laika lielāko profesionālo izaicinājumu!

- Pastāsti par kaut ko tev svarīgu, ko tu esi iemācījies pēdējā gada laikā!

- Pastāsti, ar kādām grūtībām tu pēdējā laikā saskaries darba vietā!

- Pastāsti par kādu gadījumu skolā, klasē, kuru tu veiksmīgi atrisināji!

6. Kad uzdevums izpildīts, dalībnieki sasēžas aplī un dalās ar savām sajūtām, atzin̄ām. Supervizors rosina dalībniekus izteikt savu supervīzijas pieprasījumu šai dienai, pāris teikumos aprakstīt savu supervīzijas gadījuma pieteikumu, ja tas ir noformulēts.

\section{"Palīgs"}

(avots: Фопель, 2002)

Mērķis - izstrādāt grupas noteikumus, kuri tiks ievēroti visas supervīzijas laikā, rosināt apzināties sākotnēji aktuālās supervīzijas tēmas, veicināt grupas sadarbību. Nepieciešamie materiāli - papīra lapa cilvēka augumā, marķieris, krāsaini (tostarp vairāki zili) flomāsteri.

Laiks - 60 min (6-8 dalībnieku grupai).

Darba gaita

1. Viens no grupas dalībniekiem noguḷas uz grīdas uz liela papīra (otrs variants papīrs piestiprināts pie sienas, un dalībnieks tam piekḷaujas), un kāds no kolēǵiem apvelk apkārt kontūru.

2. Norunā, ka šis būs grupas palīgs un viņš būs klāt visās grupas nodarbībās. Palīgam var dot vārdu. 
3. Pie palīga galvas dalībnieki raksta, ko vini vēlētos supervīzijas nodarbīîās un kādas tēmas būtu svarīgi izskatīt.

4. Uz ķermeņa raksta, kas katram ir svarīgs grupas darbā: 1 - kas man patīk; 2 - kas man nepatīk. To, kas šķiet svarīgākais, raksta ar zilu flomāsteru.

5. Pie kājām raksta, ar kādu ieguvumu katrs vēètos aiziet, kad būs noslēdzies grupas vai komandas supervīzijas darbs.

6. Piestiprina palīgu pie sienas grupai redzamā vietā, vai arī dalībnieki sasēžas tam apkārt.

7. Pārrunā un pastāsta, ko katrs domājis, rakstot, kas patīk un kas nepatīk, lai palīgs tiešām izpildītu palīga funkciju.

8. Pēc pārrunām vēlreiz uz A4 lapas uzraksta tos noteikumus, par kuriem grupa vienojas, ka tie tiks ievēroti.

9. Supervīzijas turpmākajā gaitā dalībnieki, sēžot aplī, pastāsta par aktuālo darbā, ar kādām problēmām saskaras un ko ir uzrakstījuši palīgam pie galvas, kā arī to, ko vēlētos darīt grupas vai komandas supervīzijās.

\section{"Komandas zïmējums"}

(avots: Фопель, 2004)

Mērķis - meklēt resursus, kā komandai vai grupai strādāt tālāk, noteikt, kāda ir pašreizējā situācija, un, strādājot grupās pa trim, saliedēt grupas dalībniekus. Nepieciešamie materiāli - vairākas A3 lapas, krāsaino krītiṇu komplekti.

Laiks - 90 min.

Metode izmantojama galvenokārt darbam ar komandu, taču var tikt pielāgota arī darbam ar grupu.

Darba gaita

1. Komandas vai grupas dalībnieki sadalās grupās pa trim.

2. Katrai grupai tiek iedota A3 lapa un trīs krāsu krītinii. Tiek lūgts uzzīmēt vienu zīmējumu, kurā būtu attēlots tās dalībnieku skatìjums par to, kas notiek komandā vai grupā. Zīmējumā jāiekḷauj atbildes uz vairākiem jautājumiem.

- Kas mums jāsasniedz?

- Kas mums traucē iet ceḷā uz mērkii?

- Kādā atmosfērā mēs strādājam?

- Kāda ir mūsu savstarpējā saskarsme?

- Kādas jūtas mēs piedzīvojam, esot šajā grupā?

Zīmējumā drīkst izmantot trīs krāsas. Vienu - lai izteiktu to, kas patīk. Otru - lai izteiktu to, ar ko katrs ir neapmierināts. Trešo - neitrāliem notikumiem. Darbam ir viena stunda laika. 
L. Vaite. Supervīijas darba metodes izglitīibas vidē

3. Kad mazās grupas ir uzzīmējušas zīmējumu, tad tiek izveidots viens liels dalībnieku aplis un viena no grupām ieliek savu zīmējumu ap̣̣a vidū. Pārējie dalībnieki apmēram 3-4 minūtes izsaka minējumus par to, kas gleznā attēlots. Tikai pēc tam pati grupa izstāsta, kas gleznā redzams. Tā visas grupas izstāsta par saviem zīmējumiem.

4. Tad seko noslēguma saruna aplī, kurā grupa var pārrunāt, kādas grūtības tā jau pārvarējusi, kādas vēl jārisina, kādas grupai ir stiprās puses.

\section{"Gadijuma izskatišana"}

Mērḳis - paplašināt supervizējamā gadījuma izpratni, rast atbildes uz supervīzijāā aktuālajiem jautājumiem (pieprasījumu), attīstīt prasmi kopā sadarboties.

Laiks - 90 min.

Metodi izmanto grupas vai komandas supervīzijai gadījuma izskatīšanai un risinājumu meklēšanai.

Darba gaita

1. Supervizējamais izstāsta savu gadījumu, grūtības un veido pieprasījumu, ko vēlētos noskaidrot supervīzijas procesā. Gadījuma izklāstam tiek veltītas 10-15 minūtes. Grupa klausās, kas un kā tiek stāstìts.

2. Supervizējamais klausās. Grupa stāsta tikai par savām sajūtām, kuras radušās, klausoties gadījuma izklāstā. Katrs no grupas dalībniekiem stāsta, ko tagad jūt.

3. Supervizējamais klausās. Grupas dalībnieki stāsta, ko ievēroja attiecībā uz to, kā tika stāstīts gadījums. Netiek izteikti vērtējumi, tikai fenomenoloǵiski vērojumi kādi akcenti bija stāstījumā, balss tonis, pretrunas stāstījumā, pauzes, ķermeṇa valoda $\mathrm{u}$. tml.

4. Supervizējamais klausās. Grupas dalībnieki tiek lūgti iedziḷināties stāstītajā un uzzīmēt vai pastāstīt, ar kādu metaforu viṇi salīdzinātu stāstīto gadījumu vai kādas asociācijas radušās.

5. Supervizējamais klausās. Grupa meklē risinājumus supervizējamā pieprasījumam - dalās ar zināšanām, pieredzi.

6. Supervizējamais pastāsta grupai, ko dzirdējis, kā jūtas, kam piekrīt un kam ne.

7. Supervizējamais klausās. Grupa apkopo iespējamos risinājumus, piedāvājumus, idejas. Katrs grupas dalībnieks tiek lūgts īsi izteikties.

8. Supervizējamais pastāsta, kas viṇam no dzirdētā bija noderīgs, ko viṇš varētu izmantot un kā risinās pieteikto gadījumu.

9. Noslēguma aplis, kur katrs dalībnieks vienā teikumā pasaka, ko svarīgu vai vērtīgu atklājis vai kādu atziṇu guvis.

Grupas vadītājam svarīgi uzmanīt, lai tiktu ievēroti katra soḷa uzdevumi, lai grupas darbs notiktu taktiski un netiktu izteikts vērtējums vai nosodījums. 


\section{"Pa solim"}

Mērķis - attīstīt prasmes un iemaņas risināt problēmsituācijas sadarbojoties.

Nepieciešamie materiāli - papīrs un pildspalva.

Laiks - $60 \mathrm{~min}$.

Darba gaita

1. Supervizors lūdz skolotājus sadalīties pāros un katru pāri apsēsties tā, lai tas varētu netraucēti sarunāties.

2. Katrs pārī esošais tiek lūgts izstāstīt kādu pašlaik aktuālu problēmsituāciju darbā (klasē, starp kolēg̣iem, sadarbībā ar administrāciju, skolēnu, viṇa vecākiem u. tml.), kuras risinājums pašlaik būtu svarīgs.

3. Supervizors lūdz katru pāri vienoties par vienu no stāstītajām situācijām, kura būtu interesanta abiem pārī esošajiem pedagogiem.

4. Pāri analizē problēmsituāciju pa soḷiem:

- 1. solis - kā problēma izpaužas ārēji. Uzraksta visas redzamās uzvedības izpausmes;

- 2. solis - apzina un uzraksta tos cēloṇus, kuri problēmai ir vienkāršāk redzami ("virspusējos" cēloṇus);

- 3. solis - analizē un cenšas saprast, kādi varētu būt patiesie (slēptie) notiekošā cēloṇi.

5. Izstrādā iespējamos problēmas risināšanas veidus un darbības, ṇemot vērā noskaidroto par problēmsituāciju.

6. Noslēgumā supervizors lūdz dalībniekus kopējā aplī pastāstīt, kā veicies, sadarbībā risinot problēmsituāciju, un kādas atziṇas ir gūtas.

\section{Metodes stresa apzināšanai un izdegšanas profilaksei}

Skolotāja darba ikdiena ir saistīta ar ciešu mijiedarbību un sadarbību ar cilvēkiem, $\overline{1} d z$ ar to izdegšanas risks ir augsts. Izdegšanas profilakse bieži vien ir viena no aktuālajām supervīzijas tēmām.

\section{"Instrukcija labizjūtai"}

Mērkisis - rosināt domāt par savu labizjūtu, par to, kas tai nepieciešams, ieklausīties kolēgos, smelties idejas.

Nepieciešamie materiāli - katram dalībniekam viena A3 zīmēšanas lapa, guašas krāsas un viena A4 lapa instrukcijas rakstīšanai.

Laiks - $90 \mathrm{~min}$.

Metode izmantojama darbā ar grupu vai komandu, vai arī individuālajā supervīzijā. 
L. Vaite. Supervīijas darba metodes izglitīibas vidē

Darba gaita

1. Grupas vadītājs lūdz pedagogus asociēt sevi ar kādu augu. Tas var būt gan dabā eksistējošs, gan izdomāts.

2. Grupas vadītājs lūdz dalībniekus izvēlēties krāsas un uz A3 lapas šo augu uzzīmēt.

3. Kad augs uzzīmēts, katrs dalībnieks tiek lūgts uzrakstīt auga kopšanas instrukciju, ietverot tajā vismaz septiņus punktus.

4. Kad darbs pabeigts, dalībniekus lūdz sadalīties grupās pa trim, kur katrs dalībnieks parāda savu zīmējumu un lēnām lasa sarakstīto instrukciju. Kāds no dalībnieku trijotnes pēc nolasīšanas veic kopsavilkumu - es dzirdu, ka tavam augam vajadzīgs, ir svarīgi u. tml.

5. Kad visi parādījuši savus zīmējumus un nolasījuši instrukcijas, dalībnieku trijotnes pārrunā, kādas pārdomas radušās, gan pildot uzdevumu, gan klausoties kolēga stāstījumā. Daloties ar pārdomām, netiek izteikti vērtējumi vai ieteikumi.

6. Pēc pārrunām katrs individuāli uzraksta, kas pašlaik viṇam būtu ḷoti nepieciešams savai labizjūtai, kā to iespējams saṇemt un kādēl tas būtu svarīgi. Būtiski uzrakstīt ne tikai to, kas vajadzīgs un kas jādara, bet noteikti arī, kādēḷ tas ir vajadzīgs, - kas mainīsies, kā mainīsies, ko tad darīs u. tml.

7. Noslēgumā dalībnieki sasēžas kopā grupas aplī un supervizors lūdz katru padalīties ar secinājumiem, kurus dalībnieki sev uzrakstījuši un vēlas īstenot.

\section{"Pilieni"}

Mērķis - apzināties savu stresu, tā izpausmes un ietekmi ikdienā, kāar āi izpaust to aktīvā, radošā darbībā.

Nepieciešamie materiāli - A4 akvareḷu papīrs, ūdens, ūdenskrāsas, trauciṇi krāsu jaukšanai, kokteiḷu salmiņi, līmlapiņas.

Laiks - 90 min.

Metode izmantojama individuālajā, grupas vai komandas supervīzijā.

Darba gaita

1. Grupa sēž aplī. Supervizors lūdz skolotājus pastāstīt, ar kādām stresa situācijām viņi visbiežāk saskaras ikdienā.

2. Dalībnieki sadalās grupās pa trīs un cits citam pastāsta

- kā sajūt un atpazīst savu stresu;

- kā tas ietekmē ikdienu.

3. Supervizors lūdz katru dalībnieku paņemt vienu A4 akvareḷu papīra lapu, ūdenskrāsas (uz vairākiem dalībniekiem var būt viens ūdenskrāsu komplekts), trauciņus krāsu sajaukšanai, trauku ar ūdeni, otu un kokteiḷu salmiņu. 
Turpmākā darba gaita:

- noklāj lapu ar ūdeni;

- ar otiņu liek uz papīra pēc izvēles dažādu krāsu piles (ūdenskrāsa sajaukta ar ūdeni), iedomājas, ka šie pilieni ir ikdienas stress, stresa situācijas, un ar salminu pūš krāsu pilienus pa lapu, cenšoties tos virzīt vai arī vienkārši brīvi pūšot, kā katrs no dalībniekiem izvēlas;

- kad darbs pabeigts, dalībnieki dod tam nosaukumu, uzraksta uz līmlapiņas un pielīmē pie sava darba.

4. Supervizors lūdz katram dalībniekam par katra kolēǵa darbu izdomāt, kādu nosaukumu viņš tam dotu, uzrakstīt uz līmlapiņas un pielīmēt pie darba.

5. Supervizējamie iepaz̄̄stas ar citu kolēǵu dotajiem nosaukumiem viṇa darbam, padomā, kā tas rezonē un par ko rosina aizdomāties.

6. Dalībnieki grupās pa trīs dalās ar savu pieredzi uzdevuma pildīšanā:

- kā tika pūstas "stresa pilītes", vai izdevās tās vadīt vai ne, kā tas sasaucas ar ikdienas stresa vadīšanu;

- kāpēc savam darbam izvēlējās tādu nosaukumu, ar ko tas asociējas;

- kādas pārdomas radās, uzzinot kolēǵu dotos nosaukumus.

7. Noslēgumā supervizors lūdz pedagogus izveidot apli un vienā vai divos teikumos pastāstīt, ko pēc veiktā uzdevuma apzinājās un kādas pārdomas radušās.

8. Tālākajā supervīzijas gaitā supervizors var rosināt pedagogus turpināt strādāt ar darba stresoru apzināšanos un analīzi, kā arīizglìtot par metodēm stresa pārvaldīšanai un relaksācijai.

\section{Avoti un literatūra}

Фопель, К. (2002). Создание команды. Психологические игры и упражнения. Москва: Генезис.

Фопель, К. (2004). Психологические группь. Рабочие материаль для ведущего. Москва: Генезис. 